\section{ASA Calendar of Events \& Deadlines}

1996

31 July Last day Endowment contributions count towards NEH match

1 August Deadline to return ballots for 1996 ASA election

15 October Deadline for proposals to host ASA Secretariat

18 October Deadline for pre-registration for Annual Meeting

23 October Deadline for meeting-rate Hyatt reservations for the Annual Meeting

1 September Deadline for submissions to ASA News

23-26 November 39th ASA Annual Meeting, San Francisco

1 December Deadline for submissions to ASA News

1997

1 March Deadline for submissions to ASA News

1 March Deadline for proposals for the Book Donation Program

15 March Deadline for submission of proposals for 1997 Annual Meeting

15 March Deadline for nominations for the International Visitors Program

15 March Deadline for nominations for the Distinguished Africanist Award

1 April Deadline to nominate members to the Nominating and Herskovits Award Committees

1 May Deadline for publishers to nominate for the Herskovits Award

1 June Deadline for submissions to ASA News

1 September Deadline for submissions to ASA News

12-15 November 40th ASA Annual Meeting, Columbus, Ohio

1 December Deadline for submissions to ASA News

1998

15 March Deadline for submission of proposals for 1998 Annual Meeting

28 October- 4/11 41st ASA Annual Meeting, Chicago
DISTINGUISHED AFRICANIST NOMINATIONS

The African Studies Association offers a Distinguished Africanist Award in recognition of lifetime distinguished contributions to African studies. Presented at the annual meeting, the award consists of a lifetime membership in the African Studies Association.

Any member of the Association is eligible to propose a candidate for the Distinguished Africanist Award. The nomination must include a vitae of the nominee, a detailed letter of nomination justifying candidature in terms of the criteria for the award, and three similar letters from ASA members seconding the nomination. At least two of the latter must be affilated with institutions other than that of the nominee. The complete dossier of the candidate must be submitted to the Secretariat of the Association by March 15, 1997, for 1997 consideration.

Criteria for the award are the distinction of contributions to Africanist scholarship, as measured by a lifetime of accomplishment and service in the field of African studies. Contributions to scholarship within and without the academic community are considered.

The selection committee for the award is composed of the Past President, the President, the Vice President, and two ASA members designated by the ASA Board of Directors. The recommendation of the selection committee is presented to the Board of Directors at its spring meeting and the final choice is made by the Board.

\section{HERSKOVITS PRIZE NOMINATIONS}

The ASA each year solicits nominations for the Herskovits Award from nearly 400 publishers of Africana in the US and (to a lesser extent) abroad. Despite our long list, we occasionally miss a publisher with a new African title. If you know of books that should be considered for the prize for 1997 and wish to be assured that they are being considered, or if you are the author of a book published in 1996, you may contact the publisher and recommend nomination of the title. A description of the criteria for nomination is listed below. Publishers may nominate as many separate titles in a given year as they desire. The deadline for nominations is May1, 1997. 